\title{
Socio-cultural aspects of non-communicable disease prevention in three villages in the West Java
}

\author{
Aspek sosial budaya dalam pencegahan penyakit tidak menular \\ di tiga desa di Jawa Barat \\ Erna Herawati $^{1^{*}}$, Yulia Sofiatin ${ }^{2}$ \\ ${ }^{1}$ Department of Anthropology, Faculty of Social and Political Sciences, Padjadjaran University \\ ${ }^{2}$ Department of Public Health, Faculty of Medicine, Padjadjaran University \\ Address: ${ }^{1,2}$ Jalan Raya Bandung Sumedang KM 21, Jatinangor 45363 \\ Email: e.herawati@unpad.ac.id
}

Article History: Received 29 April 2020; Accepted 05 August 2021; Published Online 27 August 2021

\begin{abstract}
Community responses to disease, including non-communicable diseases, are influenced by the socio-cultural system. The system shapes community knowledge and belief on diseases, as well as community attitude and practice towards prevention and treatment. Drawing on the case in West Java Province, this study aims at identifying socio-cultural aspects in preventing non-communicable diseases. This study was conducted by using a qualitative design. The data were collected through in-depth interviews and archival study. This study found four socio-cultural aspects related to disease and the prevention and treatment of disease in West Java: 1) knowledge and practice of medicine covered in a local knowledge system about the prevention and treatment of non-communicable diseases, 2) local institutions, involving social institutions ranging from families, mosque neighborhood groups, and recitation groups, 3) social actors involved, such as ustaz, traditional leaders, and youth groups, 4) local health communication, using visual and audiovisual aids. This study concludes that these four aspects must be considered in designing a socio-cultural-based non-communicable disease prevention strategy, to be effective and in accordance with the socio-cultural context in West Java.
\end{abstract}

Keywords: non-communicable disease; socio-cultural; strategy; West Java

\begin{abstract}
Abstrak
Respons masyarakat terhadap penyakit, termasuk penyakit tidak menular, dipengaruhi oleh sistem sosial budaya. Sistem tersebut membentuk pengetahuan dan kepercayaan masyarakat tentang penyakit, serta sikap dan praktik masyarakat terhadap pencegahan dan pengobatan. Berangkat dari kasus di Provinsi Jawa Barat, studi ini bertujuan untuk mengidentifikasi aspek sosial budaya pada pencegahan penyakit tidak menular. Studi ini dilakukan dengan desain kualitatif. Pengumpulan data dilakukan melalui wawancara mendalam dan studi kearsipan. Studi ini menemukan empat aspek sosial budaya yang terkait dengan penyakit dan pencegahan serta pengobatan penyakit di Jawa Barat: 1) pengetahuan dan praktik pengobatan yang dikemas dengan sistem pengetahuan lokal tentang pencegahan dan pengobatan penyakit tidak menular, 2) institusi lokal, yang melibatkan lembaga sosial mulai dari keluarga, kelompok keagamaan masjid, dan kelompok pengajian, 3) aktor sosial yang terlibat, seperti ustaz, pemuka adat, dan golongan muda, 4) komunikasi kesehatan lokal, dengan alat bantu visual maupun audiovisual. Studi ini menyimpulkan bahwa keempat aspek tersebut harus dipertimbangkan dalam merancang strategi pencegahan penyakit tidak menular berbasis sosial budaya, agar efektif dan sesuai dengan konteks sosial budaya di Jawa Barat.
\end{abstract}

Kata kunci: penyakit tidak menular; sosial-budaya; strategi; Jawa Barat

\section{Introduction}

Non-communicable diseases (NCDs) are diseases whose causes are not viruses and bacteria and are not transmitted between humans. This disease accounts for a huge number of fatalities in the world (Kim \& Oh 2013). The World Health Organization (WHO) noted that $70 \%$ of deaths worldwide in 2017 were caused by non-communicable diseases (WHO 2017). In Indonesia, the most common noncommunicable diseases are hypertension, cardiovascular (stroke), cancer, chronic lung disease, and diabetes mellitus (Kemenkes RI 2012). 
The Ministry of Health has launched the GERMAS (People's Healthy Lifestyle Movement) program and the Healthy Family program as an effort to increase public awareness to implement non-communicable disease prevention behaviors since 2016. The core of GERMAS activities is the application of CERDIK behavior (abbreviation of $\mathrm{C}=$ periodic health checks, $\mathrm{E}=$ stopping smoking, $\mathrm{R}=$ being diligent in physical activity, $\mathrm{D}=$ a balanced healthy diet, $\mathrm{I}=$ adequate rest, and $\mathrm{K}=$ managing stress) (Kemenkes RI 2017, Raksanagara 2015). The Healthy Family Program is in the form of home visits by community health center officers to collect data on various types of non-communicable diseases and strengthen community-based health efforts (UKBM). In addition to these two programs, the government has also launched the Revitalization of the Integrated Development Post of Non-Communicable Disease (Posbindu PTM) as an effort to increase community-based prevention efforts Kemenkes RI 2016). However, these programs have not been able to reduce the prevalence of non-communicable diseases in Indonesia. In fact, the prevalence of NCD in Indonesia is still increasing (Arsunan 2012, Kemenkes RI 2018, Nur \& Warganegara 2016) as shown in Table 1.

Table 1.

Increase in the prevalence of Non-Communicable Diseases in Indonesia

\begin{tabular}{lcc}
\hline \multicolumn{1}{c}{$\begin{array}{c}\text { Non-Communicable } \\
\text { Diseases }\end{array}$} & Prevalence in 2013 & Prevalence in 2018 \\
\hline Stroke & $7 \%$ & $10.9 \%$ \\
Diabetes mellitus & $6.9 \%$ & $8.5 \%$ \\
Hypertension & $25.8 \%$ & $34.1 \%$ \\
\hline
\end{tabular}

Source: Kemenkes RI (2018)

The lifestyle of the Indonesian people that increases the risk of NCD continues to occur. This is illustrated in the data from the 2018 Basic Health Research (Riskedas); the prevalence of smoking in adolescents (10-18 years) increased from $7.2 \%$ in 2013 to $8.8 \%$ in 2016 and $9.1 \%$ in 2018 (Kemenkes RI 2018). The proportion of consumption of alcoholic drinks increased from $3 \%$ to $3.3 \%$. The proportion of less physical activity increased from $26.1 \%$ to $33.5 \%$. The proportion of fruit and vegetable consumption is less in the population in 5 years, which is still very problematic, with a percentage of $95.5 \%$ (Kemenkes RI 2018).

In West Java Province, the prevalence of hypertension and stroke in 2018 was even higher than the prevalence at the national level (Kemenkes RI 2019) as illustrated in Table 2.

Table 2.

Comparison of the prevalence of Non-Communicable Diseases in West Java Province and nationally in 2018

\begin{tabular}{lcc}
\hline $\begin{array}{c}\text { Non-Communicable } \\
\text { Diseases }\end{array}$ & $\begin{array}{c}\text { West Java Province } \\
\text { prevalence }\end{array}$ & National prevalence \\
\hline Diabetes mellitus & $1.7 \%$ & $8.5 \%$ \\
Stroke & $11.44 \%$ & $10.9 \%$ \\
Hypertension & $39.6 \%$ & $34.1 \%$ \\
\hline \multicolumn{2}{c}{}
\end{tabular}

A study in Jatinangor District, West Java, found that the prevalence rate of hypertension in this region in 2014 was $37.8 \%$, or exceeding the national figure in 2016 (Fihaya et al. 2015). In this area, the tradition of botram (eating together) with a menu of nasi liwet (Indonesian rice dish cooked in coconut milk, chicken broth, and spices) with side dishes of fried salted fish, fried tofu, sambal (Indonesian traditional chili sauce or paste), and lalap (Indonesian raw vegetable salad) is very common. No specific study has been conducted to examine the relationship between this tradition and the prevalence of hypertension in the Jatinangor area. However, a medical study conducted in this area found a correlation between a preference for salty foods and high sodium intake in the 111 salty-loving residents who were involved in the study. High sodium intake is a risk factor for hypertension (Wati et al. 2015). 
In West Java, the governor has launched the GERMAS program as a promotion for the prevention of non-communicable diseases since October 2017 (Pikiran Rakyat 2017). Since then, only two regencies and one city out of a total of 27 regencies and cities in West Java have actively participated in the program; including Bandung City, Garut Regency, and Majalengka Regency. The level of community participation in the GERMAS program in the three regions is very high; Bandung City (93\%), Garut Regency (90\%), and Majalengka Regency (90\%) (Abdusalam 2017). The increase in the prevalence of non-communicable diseases and the low participation of the community in prevention efforts launched by the government is a gap that needs to be resolved.

Tumanggor (2010) stated that health efforts in Indonesia often adopt modern health and medical system for users of Western socio-cultural community backgrounds. Consequently, there are obstacles in the development of health as well as treatment and healing of diseases when applied to the Indonesian people because their natural knowledge is integrated into their supernatural knowledge which differs greatly from the values and norms of Western society. This statement by Tumanggor (2010) is in line with the results of previous studies which found that local interpretations of the concepts of healthy, sick, and disease in Indonesia are very complex. Foster \& Anderson (2006) proposed a theory regarding the etiology of disease which is believed by the public to be naturalistic (diseases are caused by natural agents, weather, etc.) and personalistic (diseases are caused by supernatural agents).

Research on obesity in the context of Javanese culture (Triratnawati 2003) and study on high blood pressure by Widyasari et al. (2014) illustrated the complex interpretation of local communities on the concept of illness and disease that is different from biomedical. Based on the biomedical context, obesity is an unfavorable condition and increases the risk of non-communicable diseases so that it must be prevented and overcome. However, Triratnawati (2003) found that being fat for the lower class in Java is a condition that is considered good and has a positive meaning. A fat body is a reflection of prosperity and good social status because a fat body is identified with the financial ability to obtain good food intake.

On the other hand, high blood pressure in ethnic Makassarese is considered a common disease. When the symptoms appear, residents relieve them with herbal medicines. If the symptoms do not subside, they go to the community health center for treatment. High blood pressure is also considered a disease of the rich, which is due to excessive meat intake because the meat is expensive and can only be consumed by the upper social class (rich people). The assumption that high blood pressure will only attack the rich makes the lower class feel no need to take preventive measures (Widyasari et al. 2014).

The habit of self-medication with herbs and over-the-counter medicines is often carried out not only because of financial difficulties but also related to the community's understanding of the concept and categorization of disease. Minor illnesses such as headache, fever, cough, and runny nose are usually self-treated. Self-medication behavior is mostly carried out even though it often has an impact on drug poisoning or other dangers due to the use of drugs that are not in accordance with the indication (Supardi \& Notosiswoyo 2005).

Previous research by Nielsen-Bohlman et al. (2004) found that health literacy and cultural literacy affected the outcomes of various efforts to improve health status. The culture encourages increased health literacy which has an impact on increasing the community's ability to know, understand, and make decisions related to health. Language is an important aspect of health education. The use of proper and easy-to-understand language in health education is an absolute must for the community. The use of health terms in the local language helps smooth health communication with the community (NielsenBohlman et al. 2004). Moreover, health education and communication will be effective when paying attention to cultural aspects which consist of three cultural components, including the form of sources of information, messages conveyed, and ways of delivering messages (Kreuter \& McClure 2004). In providing education and health services, health workers need to consider the diversity of cultural backgrounds such as beliefs, social support, and place of residence of patients (Vaughn et al. 2009). 
The studies above describe the community's understanding of the disease that is influenced by sociocultural contexts and gives rise to attitudes and behaviors that are sometimes different from those expected by health intervention programs. Thus, any health intervention strategy that aims to improve the health status of the community must be designed on a socio-cultural basis, which is by paying attention to the socio-cultural context of the target community to effectively achieve the goals (Tumanggor 2010, Isniati 2012, Purnama 2016). However, health programs in Indonesia often adopt a health system that is sourced from a health culture from outside Indonesia. Program implementation often experiences problems due to different socio-cultural contexts. As a result, the health program has not succeeded in improving the health status of the community. This study seeks to identify socio-cultural aspects in West Java that are important to consider in developing socio-cultural-based strategies for preventing non-communicable diseases to be more effective and fit the socio-cultural context of the community.

\section{Research Methods}

This study was conducted from April to November 2018 in three villages in the West Java Province, including Cilayung Village and Cipacing Village in Jatinangor District, Sumedang Regency, and Mekarsari Village in Pasir Jambu District, Bandung Regency. This study was conducted with a qualitative research design. Qualitative research aims to understand social problems or human problems by interpreting life and also the views of the informants as a whole which is reflected in their words and actions in their natural setting (Creswell 2013). Following qualitative principles, this study attempted to understand and describe the community's views on the issue of non-communicable diseases by exploring their opinions and observing their actions related to it in their daily lives.

The informants of this study were selected with the criteria of being residents of the research site, aged over 17 years, and willing to participate in the study voluntarily. In each village, 2-3 informants were selected from the category of residents suffering from one or more non-communicable diseases, family members of residents with non-communicable diseases, religious leaders (ustaz or ustazah), representatives of youth organizations, community leaders/elders, health cadres, health workers (midwives or community health center officers). The data collection techniques were carried out through 1) in-depth interviews with the informants on the topic regarding their knowledge and opinions of noncommunicable diseases, their prevention, and treatment, 2) observations involved in the daily activities of the informants related to the prevention and treatment of non-communicable diseases, and 3) study of secondary data in archives related to numeric and non-numeric data on non-communicable diseases. The data analysis in this study followed the principle of thematic analysis (Miles \& Huberman 1992). The primary data of this study were transcripts of interviews with informants, field notes, and documentation in the form of photographs. All interview transcripts, field notes, and photographs were coded and arranged in a thematic matrix. The data interpretation was based on thematic matrices.

\section{Results and Discussion}

\section{Research sites}

Jatinangor District is a semi-urban area that has been developed as an educational area since the 1980s with four universities in it. Physical development and socio-cultural changes in this region are going very fast along with the arrival of young migrants, particularly students. The migration of students to Jatinangor changed the socio-cultural characteristics of the community, from being originally rural to semi-urban with ethnic backgrounds and socio-economic status which were originally relatively homogeneous to diverse. The health facilities in this district are quite complete; there are community health centers, clinics, and type C hospitals. Meanwhile, Pasir Jambu District, especially Mekarsari Village, is a rural area located around a tea plantation belonging to the Tea and Quina Research Center (PPTK) of West Java Province. This village is located at the foot of Mount Tilu, at an altitude of 1.300 meters above sea level. The distance from the village to the District Office and Community Health Center of Pasir Jambu is about 10 kilometers. Most of the residents work as tea pickers on tea plantations, a 
few are smallholders, and dairy farmers. The only health facility in this village is a village maternity center (Polindes) managed by a village midwife and a clinic managed by PPTK in collaboration with the community health center. Being far from the community health center makes this village less exposed to health programs, including non-communicable disease prevention programs.

Based on the results of the study, four important socio-cultural aspects related to disease in West Java were found out. These four aspects describe the understanding and response of the community to diseases in general and non-communicable diseases in particular, describe the institutions and social actors who have been involved in health efforts, and describe the forms of health communication that are usually carried out by community members in West Java. These four aspects are very crucial to be considered as references for consideration in developing a socio-cultural-based non-communicable disease prevention strategy that fits the context of West Java. Integration of this strategy with programs that have been launched by the government, such as GERMAS, CERDIK, and Healthy Families also has the opportunity to increase the success of these programs in West Java.

\title{
Knowledge and practice of disease treatment
}

'Panyawat' or 'kasakit' is a term in Sundanese to refer to the disease. Disease refers to something that causes pain in the body and makes the sufferer unable to carry out daily activities. Residents in the research sites categorize the disease into mild and severe disease. Mild disease refers to the type of disease that is perceived to interfere with the body but does not prevent the sufferer from carrying out daily activities. The category of mild disease includes not feeling well/mild fever, runny nose, cough, moderate grade fever, toothache, and headache. Eating late or eating wrong meals, cold, lack of sleep, or fatigue are often believed to be causes of mild diseases. Treatment of mild diseases is usually with adequate rest, adequate eating, and warming the body. Self-medication with over-the-counter drugs purchased at the shop or with traditional medicine in the form of ingredients from medicinal plants found in the yard of the house is also often used for the treatment of mild diseases.

Meanwhile, severe disease (panyawat parna) refers to a type of disease that causes extreme pain that prevents the sufferer from carrying out routine activities and is at risk of death. Stroke, cancer, heart disease, and other diseases that cause the sufferer to lie weak are categorized as severe diseases. The definitions and categories of diseases were stated by the informants:

\begin{abstract}
'In Sundanese, the disease is 'panyawat' or 'kasakit'. The types of panyawat can be mild and severe. If it is mild, it's usually called a common illness, such as hareeng (not feeling well), muriang (fever), salesma (cold), which are commonly suffered by people. When people suffer mild disease, they can still do activities. If it is severe, it is called parna. People with this disease cannot do activities because they must be treated. Usually, when people suffer from parna, they will be hard to heal, they can even die" (CIC, health cadre, Cilayung Village).
\end{abstract}

"Hareeng (mild fever) is felling panas tiris (cold). Colds, nyeri mustaka (headache) but still able to work. For stroke, the sufferers are gering parna, they can't go anywhere. They usually must be treated" (MIL, Cilayung Villager).

Based on the understanding of the community, the causes of severe diseases are very diverse. Hereditary factors, depression, fatigue, even 'parabun' or magic are believed to cause severe diseases. Severe diseases that appear suddenly and have no cause through biomedical testing, and do not work with biomedical treatments, are often related to magic. Residents are aware that severe diseases are believed to lead to death if it is not immediately treated and handled at a health institution. Residents believe in the effectiveness of biomedical treatment for severe diseases, so they always go to health services if they suffer from severe diseases. Home care for severe diseases is usually only carried out if there is a cost constraint because treatment for severe diseases usually cannot be done in a short time so it costs quite a lot. For severe diseases that are believed to be caused by magic, the treatment is usually not by briring the patient to the hospital but to the ajengan (religious figures who have the ability to treat supernaturally with prayers). 
Traditional medicine in the form of herbal ingredients is used by the community for the treatment of mild and severe disease categories. Traditional medicine is made by hand from ingredients in the yard of the house, purchased at the market, or at a drug seller. Medicines purchased are usually brewed or boiled at home. The community is aware of the slow impact of traditional medicine when compared to biomedical drugs, but they believe that its efficacy and side effects are safer for the body than chemical drugs. Besides, some traditional medicines which are cheaper than chemical drugs are also the reason why people use them.

Regarding non-communicable diseases, the community is not familiar with the term and does not have adequate knowledge about it. The community knows the names of hypertension which in local terms is referred to as 'tensi' (literally, tension), diabetes mellitus, or known as 'kencing manis' or diabetes, stroke, and heart disease. However, they do not know that the diseases are biomedically included in the non-communicable disease category.

The lack of vocabulary in Sundanese regarding non-communicable diseases is not only due to the lack of knowledge of the community about these diseases but also due to the lack of prevalence of these diseases in Sundanese society in the past. The names of diseases that have equivalents in Sundanese are probably diseases that are common to the community: including batuk gangsa (TB), kuris (pox), gondongeun (mumps), hapur (pityriasis versicolor); mengi (asthma); tampek (measles).

Recently, the use of Sundanese is being swept out and being replaced by Indonesian. The new terms in Indonesian, including names of diseases, can be accepted and understood by the Sundanese people, so they do not try to create their equivalents in Sundanese. Among non-communicable diseases, hypertension and diabetes mellitus may have existed in the past, so they have local terms. Meanwhile, other diseases such as stroke, heart disease, and cancer do not have local terms. Nyeuri mastaka (headache) and rieut (dizziness) are terms that are often associated with symptoms of tensi.

In the local disease category, hypertension and diabetes are categorized as moderate to severe diseases. Both are in the moderate category when the sufferer can still carry out daily activities. However, if the disease has caused the sufferer to only lie down and cannot do any activities, it is categorized as a severe disease. Regarding the etiology/causes of non-communicable diseases, the consumption of sweet foods and heredity are believed by the community to be the cause of kencing manis. Tensi, heart disease, and stroke are caused by too many thoughts (depression), consumption of salty foods, fatigue, heredity, and age. Women suffer from tensi more because it is associated with gender. The link between thoughts, tensi, and gender was stated by one resident:

\footnotetext{
"Those who suffer from tensi are usually women, not men. Women like to get dizzy when it comes to organizing and making money. When they feel dizzy, usually, their blood pressure immediately becomes high, their vision is blurry, all they want is to rest, Miss..." (SRI, Cilayung Villager).

"Women have a lot of burdens on their minds. They must be able to do this and that with a limited economy. I actually don't want to think about it, but how? If we end up having high blood pressure, it's reasonable hahaha" (ENO Cipacing Villager).
}

The relation between depression and blood pressure is thought to be greater than that with salty food intake. This was stated by one resident:

"Eating not salty food is not tasty. The food is usually salted fish, with soup. Tofu can also be cooked into soup. For soup, it should be cooked using salt and flavoring. But, we won't have high blood pressure if we don't think much" (AIS, Cilayung Villager).

Tensi and kencing manis are the most common diseases suffered by residents in the research sites. Symptoms of tensi that are understood by the community are headaches and neck pain. In fact, these symptoms do not always indicate hypertension. Some residents do not even feel any symptoms even 
though their blood pressure is very high $(>200 / 100 \mathrm{mmHg})$. They can still carry out daily activities and even work hard, such as the experience of informant TUT as a tea picker on tea plantations. Like most residents, the informant associated tensi with thoughts:

"I found out that my blood pressure was high when I went to see Dr. Pirman. He said it was 200. Now I'm still taking medicine, it's been a long time, for years. I have to take medicine every day. At that time, I didn't go to the doctor because I had high blood pressure, but because I wasn't feeling well. Back then, I had family problems, so I became sick. But now the problem is solved. The blood still hasn't been low. But I don't feel anything in my body. Working in the garden, it's normal. Just be happy to be healthy" (TUT, Mekarsari Villager).

Treatment for tensi that the community does is to rest and sleep. Biomedical drugs for high blood pressure consumed by the community are Amlodipine and Captopril. They first obtain the drug from a community health center doctor or midwife. When the medicine has run out, they can buy it without a prescription at the pharmacy. In addition to biomedical drugs, they also use traditional ingredients to lower blood pressure, such as boiled rubber fig (Ficus elastic) leaves, mangosteen peel decoction, soursop leaf decoction, and avocado leaf decoction. Eating cucumber, boiled chayote, and bilimbi is also believed to lower blood pressure.

Diabetes mellitus is a non-communicable disease that is also suffered by many residents in the research sites. The symptom of this disease, according to the residents, is urine surrounded by ants. The community realizes that diabetes can cause death faster than high blood pressure. In addition, the impact of diabetes is also perceived by sufferers as more severe than high blood pressure. According to the community, there are two types of kencing manis, consisting of wet and dry. Wet diabetes refers to a condition in which the sufferer experiences wounds that are difficult to heal, even causing the body's organs to experience severe infections and need to be amputated. Meanwhile, dry diabetes refers to a condition in which the sufferer experiences very drastic weight loss, but is not accompanied by wounds.

The main cause of diabetes in the community's understanding is heredity. This factor is considered more decisive than a high-sugar and carbohydrate diet. This disease is included in the category of severe disease when it has entered an acute period, which is when an open wound occurs in 'wet diabetes'. According to the community, treatment for kencing manis at an acute period requires hospitalization because it requires sugar-lowering drugs which are not freely sold in pharmacies. Treatment with traditional medicine is also carried out by consuming bitter-tasting leaves, which are believed to lower blood sugar levels. The decoction of nitobe chrysanthemum (Tithonia diversifolia) leaves which is first dried is believed by the community to lower blood sugar levels.

Definitions of disease and disease categories, including non-communicable diseases, suggested by the community at the research sites indicate local knowledge systems regarding categories, etiology, and treatment of diseases. This local knowledge system is often different from biomedical concepts, for example, in terms of disease etiology. Biomedical causes of disease are viruses, bacteria, amoeba, or fungi; while according to local knowledge are thoughts, heredity, fatigue, lack of sleep, and depression, even magic. This finding is in line with research conducted by Widyasari et al. (2014) in the Makassar ethnic group and Triratnawati (2003) in the Javanese ethnic group, as well as the theory proposed by Foster \& Anderson (2006) regarding the etiology of disease, including naturalistic (the disease caused by natural agents, weather, etc.) and personalistic (the disease caused by supernatural agents). Referring to the theory of disease etiology according to Foster and Anderson, the community in the research sites used more naturalistic concepts to explain the causes of disease than personalistic concepts. This is evident in the mention of food, depression, heredity, and diet as the cause of disease, as opposed to magic. The local knowledge system about this disease is a form of local wisdom in the local health culture and is an important aspect to be considered and integrated with developing disease prevention strategies, including NCDs because the knowledge system will shape community understanding and practice on non-communicable diseases. 


\section{Social institutions and disease prevention}

The involvement of various stakeholders, including social institutions, is highly recommended by the government in the prevention and control of NCDs. Integrated health services post (Posyandu) is the only social institution currently involved in community health programs. This study found that other social institutions, including the family and religious institutions (mosques and recitation groups), are potential institutions to be involved in the prevention of non-communicable diseases.

Several previous studies have found that the family plays an important role in the care of people with non-communicable diseases (Prasetyo 2012, Melia 2016, Firmansyah et al. 2018). This study also found that the family is the smallest social institution in society but has the most important role in socialization and socio-cultural enculturation, including in terms of health. In these institutions, individuals receive education on various topics for the first time, including health. The development of health behaviors and beliefs begins in the family, including lifestyles that determine individuals to be vulnerable or to avoid NCDs. However, although the family is a potential institution, the family has not been optimally involved in preventing NCDs yet until now.

Diet patterns are remarkably crucial in the context of NCD. Dietary knowledge and behavior are formed in the family. The mother's role is very important in the development of her family's diet pattern because she is the provider of the daily menu for her children and husband, whether she prepares it herself or buys it from a shop. The community's stories illustrate this aspect:
"I am the one preparing the food every day. Sometimes I buy it, sometimes I cook it myself. It just depends on the situation. My husband and children just eat what is provided. Sometimes they eat out when I'm not cooking. The menu is varied. They like vegetables, most often I cook soup. My son eats sausage, nuggets" (ROS, Cipacing Villager).
"The daily menu is whatever is provided in the house. But, I like common carp pindang, bala-bala (vegetable fritter). When I eat them, it makes me feel good to sleep. My wife provides the food, but sometimes I can also make it myself" (ALE, Cipacing Villager).
"I often eat noodles, with eggs and rice. It's easy to cook. My mother doesn't forbid how much I eat, it's free. As long as I make it myself" (GIL, Mekarsari Village Youth).

Apart from being a place for socializing health traditions, the family is also the most important health care institution. In Sundanese ethnic group, the ties between extended family members are very close so that the concept of family does not only refer to the nuclear family (father-mother-child) but also the extended family. In many cases, treatment of the disease involves the role of the extended family:

\footnotetext{
"Mr. X is my brother. When he was sick (diabetes) until he died, he was treated here in this house by my brothers and me. He had a wife, but she was no longer willing to take care of him. Well, what we can do? It's unfortunate if no one takes care of him. He couldn't do anything, especially after his leg was amputated" (DED, Mekarsari Villager).
}

Families with NCD experience tend to have more awareness of NCDs compared to families who have never been exposed to NCDs. The NCD experience also changes the behavior of family members in prevention efforts, for example, they become more attentive to NCD issues:

\footnotetext{
"When my uncle was sick and hospitalized, I often talked to the doctor, so I knew what caused my uncle's illness. I also know what to do to keep away from the disease. I'm also worried now if I suffer that disease too" (NEN, Mekarsari Village)
}

Based on the statements of the community, it can be concluded that the family is a social institution that has the potential to be involved in a socio-cultural-based NCD prevention strategy. This institution is not only a place for socialization and enculturation of healthy traditions from an early age but also as a health care institution. 
On the other side, mosques and recitation groups are institutions that can function as socialization for the prevention of non-communicable diseases. Islam is the religion of the majority of people in West Java. The recitation groups thrived up to the hamlet level. Mosques and recitation groups are the most active social institutions. The recitation schedule is usually held at least once a week. Recitation groups are differentiated by genders, such as recitations for women and men. The women's recitation is usually held in the mosque in the afternoon after the Asr prayer, while the men's recitation is usually held in the mosque in the evening after the Isha prayer. The recitation group has many members because almost all residents are members. The number of members and attendance at the recitation always exceeds the number of attendees at the integrated health services post (Posyandu). This was confirmed by several residents:

\footnotetext{
"Women's recitation in this area is every Monday afternoon; the attendees are around 40 people. If someone holds an event, like marhabanan, it can be even more. For the Posyandu, the attendees are usually around 20 people. Even though there are many parents who have toddlers, not all of them come to Posyandu. While for the recitation, it is quite often that people come" (ROH, Cipacing Villager).

"Men are busy at work; usually until late in the afternoon. For example, if there is an invitation to a meeting during working hours, they can't come. While for the recitation, it is held at night, there are usually many who can attend it" (ENT, Cipacing Villager).
}

The main agenda of the recitation is usually filled with sermons by the ustaz and reading verses of the Quran together. Besides, there is always an announcement session at each event. The announcement session has the potential to become an arena for the promotion of NCD prevention among recitation participants.

"Yes, it is very possible if information about NCD is inserted in the recitation event. During
the preaching of sermons, I sometimes also urge and pray that all congregants take care of their
health. If we are healthy, we can worship solemnly" (AGS, Religious Leader in Cipacing Village).

In Cipacing Village and Mekarsari Village, mosques and recitation groups are potential institutions for health promotion. The community stated that the provision of health information at the end of the recitation session is useful in increasing knowledge. In Hamlet 18 of Cipacing Village, the mosque is the center of activities in the hamlet, both religious and non-religious activities. The integrated health services post activities and other activities are held in the courtyard of the mosque. Announcements of activities are also made through loudspeakers in the mosque.

The potential of religious institutions as an arena for health promotion has been scientifically proven (Levin 2016). For example, in Africa, the church has become a place for treating mental illness (Hays \& Aranda 2016). At the research sites of this study, mosques and recitation groups are potential institutions for the promotion of NCD prevention because these institutions are an arena where the community gathers and become an arena for changing people's behavior through social actors, particularly the ustaz.

\section{Social actors and disease prevention}

Health workers are the social actors most trusted by the community in terms of health information. However, they can only carry out their duties in a very limited time and scope. Midwives are the only health workers stationed in the village but they focus more on maternal and child health than on noncommunicable disease issues. The only social actors involved in health issues in the village today are health cadres. Health cadres often receive health training and information, including NCD. However, cadres often do not feel confident in conveying information about NCD to the community because they feel they have not mastered the NCD material. They are only confident in conveying information about the health of mothers and children. This is as stated by a health cadre below: 
"I've participated in NCD training in 2015. But I'm not confident about providing Information, Education, and Communication (IEC) or establishing an Integrated Development Post (Posbindu). I'm afraid if I make mistakes. I'm still not sure. Meanwhile, the integrated health services post (Posyandu) and Child Identity Cards (KIA) have been developed for a long time, so many people understand them well" (EMA, Cadre in Cilayung Village).

The low self-confidence of cadres in conveying information about NCDs is exacerbated by the low level of community trust in cadre knowledge. This can be seen in the expression of a resident, "For the cadre, I think the focus is on the health of babies and toddlers, right? If it's about the disease, the person in charge should be a doctor or a midwife, right?' (NAN, Cipacing Villager).

Other potential social actors to be involved in the promotion of NCD prevention are ustaz (religious leaders), traditional leaders, and youth leaders. Ustaz is a potential figure in changing public health behavior because they have experience in providing spiritual advice aimed at changing the behavior of members of the recitation participants. Moreover, the ustaz has a very high social authority. They are respected by the community because of their mastery of religious knowledge. The potential of ustaz as health educators has been proven in several previous studies (Rujis et al. 2013, Pramesona \& Taneepanichskul 2018, Padmawati et al. 2019).

In Cipacing Village, the important role of the ustaz in health promotion was stated by a cadre:

"In here, the ustaz is listened to more than the cadres. For example, if he is asked to help with NCD counseling, he will be definitely willing to. At the very least, if the ustaz says about it, the community will more likely listen to him" (YUY, Head of Cadre of Hamlet 18 of Cipacing Village).

In Cipacing Village, the ustaz has a unique and precise way of conveying health information. He combines it with the religious material he presents so that the community can understand the link between religion and health issues. For example, AGS at Hamlet 18 of Cipacing Village in a sermon said:

"Health is a gift from God that we must always be grateful for. A form of gratitude is to protect it from various diseases, which can prevent us from worshiping Allah Swt. For example, if we have high blood pressure, then we're dizzy, how is it possible to worship solemnly?" (AGS, Religious Leader in Hamlet 18 of Cipacing Village).

Ustaz Agus' strategy in conveying an appeal regarding the importance of maintaining health for the smooth running of worship shows how they are potential actors in health promotion. Traditional leaders also have high social authority but have not been involved in the prevention of NCDs. They understand very well the practices related to local traditions that function to prevent and treat disease. In addition, they have memories of various past dietary patterns. The Sundanese had a diet high in vegetables in the past. The tradition of eating vegetables in a raw condition (lalapan), and cooking methods by boiling and steaming are some of the natural traditions of the dietary pattern that can prevent NCDs.

Besides ustaz and traditional leaders, young people who become role models for their peers are potential social actors to be involved in the promotion of NCD prevention. Effective NCD prevention should be carried out at the earliest possible age. Adolescence is the most important period for forming positive health behaviors. Young people have the ability to use mobile phones that are connected to the internet so that they can find the latest information about NCDs and share it with their peers through social media. Young people are also able to share information in their own style so that the information content is easily accepted by their peers. "If they want to look for health information, the internet is the easiest way. They only need to click it. Sometimes the information is also from their friends but then they will search on the internet for more details" (PAN, Youth in Cilayung Village). 
Mekarsari Village, even though located at the foot of the mountain, has great potential for young people. They are very literate with technology and actively seek information on the internet. They have basic knowledge about non-communicable diseases and how to prevent them. They get information about it from the internet.

"Yeah, I've heard of high blood pressure disease. That's what people suffer when they often get angry. The causes, according to the internet, are because the people angry frequently, stressed, and also because they eat too much salty food." (RID, Youth in Mekarsari Village).

The statements of PAN and RID illustrate how young people have their own way of seeking health information. Unlike the generation of their parents who trust information directly from health workers, young people trust the internet, especially if the source is also from health workers.

The involvement of young people in changing health behavior in the community, including in preventing NCDs, can be a breakthrough, especially to reach out to their peers. The success of young people in changing the health behavior of their peers is shown in the results of a study by Nurmala et al. (2019) regarding the role of peer-educators in senior high schools in Surabaya in drug prevention; and Purwanti \& Devhy's (2020) study on the role of peer groups in smoking prevention. Beyond the context of health, the role of young people in Indonesia in social and policy change has also proved important; it is not only for their peers but for the entire nation. The results of Parker \& Nilan's study (2013) found enough evidence of the important role of young people in Indonesia as drivers of social and political change since the Reform Era.

\section{Local health communication model}

The availability of information about non-communicable diseases in the community is still very limited. The advertisement for the People's Healthy Lifestyle Movement (GERMAS) from the Ministry of Health that was broadcast on television is the only audiovisual information available and is considered useful by the community. Audiovisual information is very popular with the community because it is in line with their daily communication model, particularly oral communication.

"Such information about diseases is very needed. But if I read it myself, sometimes I don't understand it, but if it is explained while talking, sometimes I can understand it better. Then, for example, if there is an example of the type of food that can or should not be eaten that causes a certain disease, that would be clearer too" (CAN, Youth in Mekarsari Village)

Besides, pictures or photos are also preferred over writing because they are easier to understand:

"I want to tell the community but the cadres don't have the tools to explain it to the community about non-communicable diseases. Well, what we can do? For example, if there are billboards or something like that which contains pictures or photos of food or habits that make us sick, that's better. It will be even better if they are displayed in a place where many people used to be there like in the hamlet hall" (IDA, Cadre in Cipacing Village).

If the form of information is in writing, the community prefers simple language and local terms for the health scope so that it is easy to understand. The language used by the community in oral communication, including in terms of health communication, is a mixture of Sundanese and Indonesian. The choice of communication and information model was conveyed by a resident, "If the explanation is about a disease, it doesn't matter whether the language is Indonesian or Sundanese. The important thing is that the language is easy to understand" (RIZ, Cipacing Villager).

Regarding the content of health information, based on the results of interviews with the community, the desired information is about the causes of the disease, symptoms, prevention, and treatment. 
"There has never been any information about such a disease (GERMAS advertisement) even though it is important. There are a lot of people here who suffer from the disease. But we don't know what causes it and whether it can be treated or not. So, I think it is important to have that information" (DED, Head of the Hamlet in Cipacing Village).

On the other hand, the village midwives on duty at the research sites are the health workers who interact the most with the community members. They stated that the availability of NCD information materials is very limited. The existing materials are not easy to convey and they recognize the need for information materials that are more practical than the existing ones, as stated by a midwife below:

\begin{abstract}
"There are guidelines for health workers. But it's not easy to convey it to the community. For example, the CERDIK book from the ministry. The contents are complete, but if we want to transfer the information from the book to the community, it takes a lot of effort, hehehe. If there is an information package that can be provided directly to the community, it's better for us" (NOK, Midwife in Mekarsari Village)
\end{abstract}

In terms of content, health workers suggest that the content of information materials is simpler and closer to everyday life so that the information is easily understood by the community, as stated by the following midwife:

"For example, for information about healthy food, the picture should be of cheap vegetables or fruit sold in stalls. So, the perception of residents about vegetables and fruit is what is available around them. Not those they have to buy at the supermarket. For example, the picture or photo in the brochure is not expensive apples or grapes but papaya, oranges, guava, mango, which are easily obtained by the community" (REV, Midwife in Cipacing Village).

In addition to using examples that are close to everyday life, the midwife also recommends the promotion of the original Sundanese diet which is considered healthier and cheaper, as stated by the midwife SYS below:

"In Sunda, there are actually many healthy diet menus. Consumption of vegetables is a lot, for example, lalapan. Every meal must have lalap and sambal. Even though they eat salted fish, it's just a little, and it's balanced with lalap. Then, about fish consumption. For example, common carp pepes, it's not fried, it's healthier. But nowadays, eating Sundanese food is should be in a restaurant. At home, the menu will be seblak, instant noodles, fritters, hahaha. Maybe it needs to be promoted again" (SYS, Midwife in Cisempur Village and Cipacing Villager).

Based on the results of interviews with the community and midwives, it can be concluded that oral communication is the model chosen by the community in delivering health information. The use of visual and audiovisual aids is also preferred over writing because it helps their understanding. The preferred information content is examples that are close to everyday life so that they are easy to follow.

Health communication is a process of information transfer between the giver and recipient of information with the aim of promoting, maintaining health, and changing health behavior (Liliweri 2011). The findings of this study show that oral health communication takes place in the local language, which is Sundanese, so that it is easy for the community to understand. This is in accordance with the results of the study by Hendraningrum (2018) about health communication in the context of Sundanese culture which is mostly carried out in local languages. Based on the explanation, the health communication strategy in making models, content, and methods of delivering information should be adapted to the social and cultural situation of the community so that the purpose of information transfer is achieved.

The form of a socio-cultural-based strategy that can be developed by paying attention to these four sociocultural aspects is, for example, making Information, Education, and Communication (IEC) materials using terms in the local language (Sundanese). Local social institutions, such as the majelis taklim (Islamic forum) and the pop-up market can be used as a forum to deliver IEC, by involving social actors 
such as young people, religious leaders, and community leaders as information transmitters and noncommunicable disease surveillance officers. IEC practices can be embedded in daily social interactions in the community. Further, the practice of traditional medicine and prevention using herbs can be integrated with medical prevention. Such a strategy makes prevention efforts no longer limited to the scope of health institutions and becomes the sole obligation of health workers, but is integrated with the sociocultural system that exists in the community and involves all social actors in the community. This method also allows the community to be actively involved in prevention efforts and increases the success of prevention efforts.

\section{Conclusion}

Based on the results of this study, it can be concluded that in formulating a socio-cultural-based noncommunicable disease prevention strategy, it is necessary to pay attention to and consider socio-cultural aspects related to disease, prevention, and treatment. In three villages in West Java, there are four important aspects involved, including: first, the aspect of knowledge and practice of disease treatment, which are covered with a local knowledge system as well as a manifestation of local wisdom in the local health culture and become an important aspect to be considered and integrated with developing disease prevention strategies, including NCDs, because the knowledge system will shape the understanding and practice of the community on non-communicable diseases. Second, the institutional aspect, which involves families, mosque neighborhood groups, and recitation groups. The family is a social institution that has the potential to be involved in a socio-cultural-based NCD prevention strategy. This institution is not only a place for socialization and enculturation of healthy traditions from an early age but also as a health care institution. Meanwhile, religious institutions in mosques and recitation groups are potential institutions for the promotion of NCD prevention because they are supported through social actors, particularly ustaz.

Third, social actors play a role in disease prevention, such as religious leaders, traditional leaders, and young people. Ustaz has a unique way of conveying health information by combining it with the religious material presented so that the community can understand the link between religion and health issues. Meanwhile, traditional leaders are considered to understand the practice of treatment with local traditions through various patterns of treatment in the past. Young people or youth are considered to have the ability to use information technology, so they can find the latest information about NCDs. Young people are also able to share information in their own style so that the information content is easily accepted by their peers. Fourth, the aspect of local health communication, that is with visual and audiovisual aids which is preferred over writing because they are easy to understand. The preferred information content is examples that are close to everyday life, this is the model that the community chooses in delivering health information. The strategy developed based on these four aspects, when synergized with programs that have been launched by the central government and local governments in West Java, will be more effective in producing socio-cultural behaviors that lead the community to establish healthy lifestyles, and ultimately reduce the prevalence of non-communicable diseases in West Java Province.

\section{References}

Abdusalam MS (2017) 3 daerah di Jabar ini dinilai miliki gerakan masyarakat sehat di terbaik. [Accessed 03 December 2019]. http://jabar.tribunnews.com/2017/11/09/3-daerah-di-jabar-ini-dinilai-milikigerakan-masyarakat-sehat-di-terbaik.

Arsunan AA (2012) Epidemiologi Penyakit Tidak Menular. Buletin Jendela Data dan Informasi Kesehatan. Jakarta: Pusat Data dan Informasi Kementerian Kesehatan Republik Indonesia.

Creswell JW (2013) Qualitative Inquiry \& Research Design: Choosing Among Five Approaches. $3^{\text {rd }}$ Edition. Thousand Oaks CA: Sage.

Fihaya FY, Sofiatin Y, Ong PA, Sukandar H, \& Roesli R M (2015) Prevalence of hypertension and its complications in Jatinangor 2014. Journal of Hypertension 33: e35. https://doi.org/10.1097/01. hjh.0000469851.39188.36. 
Firmansyah RS, Lukman M, \& Mambangsari CW (2018) Faktor-faktor yang berhubungan dengan dukungan keluarga dalam pencegahan primer hipertensi. Jurnal Keperawatan Padjadjaran 5 (2):197-213. https://doi.org/10.24198/jkp.v5i2.476.

Foster GM \& Anderson B (2006) Antropologi Kesehatan. Jakarta: Universitas Indonesia Press.

Hays K \& Aranda MP (2016) Faith-based mental health interventions with African Americans: A review. Research on Social Work Practice 26 (7):777-789. https://doi.org/10.1177/1049731515569356.

Hendraningrum R (2018) Budaya dan komunikasi kesehatan (studi pandangan kesehatan pada masyarakat Sunda dalam tradisi makan lalapan). LUGAS Jurnal Komunikasi 2 (1):13-19. https:// doi.org/10.31334/j1.v2i1.118.

Isniati (2012) Kesehatan modern dengan nuansa budaya. Jurnal Kesehatan Masyarakat 7 (1):39-44. https://doi.org/10.24893/jkma.v7i1.106.

Kemenkes RI (2012) Penyakit tidak menular. [Accessed 19 December 2019]. https://pusdatin. kemkes. go.id/article/view/13010200029/penyakit-tidak-menular.html.

Kemenkes RI (2016) Menkes: Mari bersama sukseskan GERMAS dan keluarga sehat. [Accessed 19 March 2019]. https://sehatnegeriku.kemkes.go.id/baca/rilis-media/20160331/1514617/menkesmari-bersama-sukseskan-germas-dan-keluarga-sehat/.

Kemenkes RI (2017) Petunjuk Teknis Penyelenggaraan CERDIK di Sekolah. Jakarta: Dirjen Pencegahan dan Pengendalian Penyakit Tidak Menular.

Kemenkes RI (2018) Riset Kesehatan Dasar (RISKESDAS) 2018. Jakarta: Kementerian Kesehatan Republik Indonesia.

Kemenkes RI (2019) Laporan Provinsi Jawa Barat Riskesdas 2018 [Accessed 30 June 2021]. http:// diskes.jabarprov.go.id/dmdocuments/18b7496203a25fb786f9bd84bdfe13b7.pdf.

Kim HC \& Oh SM (2013) Noncommunicable diseases: Current status of major modifiable risk factors in Korea. Journal of Preventive Medicine and Public Health 46 (4):165-172. https://doi.org/10.3961/ jpmph.2013.46.4.165.

Kreuter MW \& McClure SM (2004) The role of culture in health communication. Annual Review of Public Health 25: 439-455. https://doi.org/10.1146/annurev.publhealth.25.101802.123000.

Levin J (2016) Partnerships between the faith-based and medical sectors: Implications for preventive medicine and public health. Preventive Medicine Reports 27 (4):344-350. https://doi.org/10.1016/j. pmedr.2016.07.009.

Liliweri A (2011) Dasar-Dasar Komunikasi Kesehatan. Yogyakarta: Pustaka Pelajar.

Melia Y (2016) Upaya keluarga dalam penyembuhan pasien penyakit jiwa: Studi pada pasien penyakit jiwa di RSJ HB. Sa'anin Padang. Jurnal Ilmu Sosial Mamangan 5 (2):102-112. https://doi. org/10.22202/mamangan.2325.

Miles M \& Huberman M (1992) Analisis Data Kualitatif. Jakarta: Universitas Indonesia.

Nielsen-Bohlman L, Panzer AM, \& Kindig DA (2004) What is Health Literacy? In Health literacy:A Prescription to End Confusion. Washington DC: National Academies Press.

Nurmala I, Muthmainnah, Diana R, \& Dwi PE (2019) Gender and norms related to an intention for participating in counselling session by peer educator. Masyarakat, Kebudayaan dan Politik 32 (1):105-113. http://dx.doi.org/10.20473/mkp.V32I12019.105-113.

Nur NN \& Warganegara E (2016) Faktor perilaku penyakit tidak menular. Medical Journal of Lampung University (MAJORITY) 5 (2):88-94.

Padmawati RS, Heywood A, Sitaresmi MN, Atthobari J, MacIntyre CR, Soenarto Y, \& Seale H (2019) Religious and community leaders' acceptance of rotavirus vaccine introduction in Yogyakarta, Indonesia. BMC Public Health 19 (1):368. https://doi.org/10.1186/s12889-019-6706-4.

Parker L \& Nilan P (2013) Adolescents in Contemporary Indonesia. Routledge.

Pikiran Rakyat (2017) Pemprov Jabar usung gerakan masyarakat hidup sehat. [Accessed 8 January 2020]. https://www.pikiran-rakyat.com/bandung-raya/2017/10/18/pemprov-jabar-usung-gerakanmasyarakat-hidup-sehat-411781.

Pramesona BA \& Taneepanichskul S (2018) The effect of religious intervention on depressive symptoms and quality of life among Indonesian elderly in nursing homes: A quasi-experimental study. Clinical Interventions in Aging 13: 473-483. 
Prasetyo AS (2012) Analisis faktor-faktor yang berhubungan dengan self-care pada asuhan keperawatan pasien hipertensi di RSUD Kudus. Thesis, Universitas Indonesia, Depok.

Purnama Y (2016) Kearifan lokal masyarakat Jatigede dalam pengobatan tradisional. Patanjala: Jurnal Penelitian Sejarah Dan Budaya 8 (1):69-84. https://doi.org/10.30959/patanjala.v8i1.60.

Purwanti IS \& Devhy NLP (2020) Efektivitas kelompok sebaya dalam perilaku berhenti merokok di SMA swasta Kota Denpasar. Jurnal Kesehatan Indonesia 11 (1):14-19. http://dx.doi.org/10.33657/ jurkessia.v11i1.241.

Raksanagara A \& Raksanagara A (2015) Perilaku hidup bersih dan sehat sebagai determinan kesehatan yang penting pada tatanan rumah tangga di Kota Bandung. Jurnal Sistem Kesehatan 1 (1):30-34. https://doi.org/10.24198/jsk.v1i1.10340.

Rujis WL, Hautvast JL, Kerrar S, Van der Velden K, \& Hulscher ME (2013) The role of religious leaders in promoting acceptance of vaccination within a minority group: A qualitative study. BMC Public Health 13 (1):511. https://doi.org/10.1186/1471-2458-13-511.

Supardi S \& Notosiswoyo M (2005) Pengobatan sendiri sakit kepala, demam, batuk, dan pilek pada masyarakat di Desa Ciwalen, Kecamatan Warungkondang, Kabupaten Cianjur, Jawa Barat. Majalah Ilmu Kefarmasian 2 (3):134-144. https://doi.org/10.7454/psr.v2i3.3390.

Triratnawati A (2003) Problematika kegemukan kelas bawah: Tinjauan antropologi kesehatan. Mutiara Medika: Jurnal Kedokteran Dan Kesehatan 3 (2):78-90. https://doi.org/10.18196/mmjkk.v3i2.1699.

Tumanggor R (2010) Masalah-masalah sosial budaya dalam pembangunan kesehatan di Indonesia. Jurnal Kedokteran Dan Kesehatan 12 (2):231-254. https://doi.org/10.14203/jmb.v12i2.111.

Vaughn LM, Jacquez F, \& Baker RC (2009) Cultural health attributions, beliefs, and practices: Effects on healthcare and medical education. The Open Medical Education Journal 2: 64-74. https://doi.or g/10.2174/1876519X00902010064.

Wati YAE, Hamied LIA, Martiana A, Sofiatin Y, \& Roesli RM (2015) Moderate correlation between high salt taste preference and high sodium intake. Journal of Hypertension 33: e35. https://doi. org/10.1097/01.hjh.0000469850.39188.7f.

WHO (2017) Noncommunicable diseases progress monitor 2017. [Accessed 20 December 2019]. https://doi.org/10.2766/120051.

Widyasari R, Rahmad M, Al Qorni U, \& Pratiwi NL (2014) Si Pembunuh Senyap Tinggi Dara: Seri Etnografi Kesehatan. Jakarta: Kerjasama Pusat Humaniora, Kebijakan Kesehatan dan Pemberdayaan Masyarakat, Badan Penelitian dan Pengembangan Kesehatan Republik Indonesia dan Lembaga Penerbitan Balitbangkes. 